\section{Evaluasi Sistem Penilaian Rekognisi Pembelajaran Lampau}

\author{
Fitri Trapsilawati, Subagyo, Teguh Ariyanto, \\ Muhammad Kusumawan Herliansyah, \\ Suryo Purwono
}

Dosen dan Pengelola Program Studi Program Profesi Insinyur, Fakultas Teknik, Universitas Gadjah Mada.

psppi.ft@ugm.ac.id
Program Studi Program Profesi Insinyur Fakultas Teknik Universitas Gadjah Mada (PSPPI FT UGM) telah mengembangkan sistem konversi dan sistem penilaian untuk program Rekognisi Pembelajaran Lampau (RPL) yang mengacu pada bakuan kompetensi Persatuan Insinyur Indonesia (PII). Sistem penilaian RPL (SP RPL) ini telah diimplementasikan dalam proses penilaian RPL pada beberapa periode peserta PSPPI FT UGM. Paper ini fokus pada evaluasi hasil penilaian RPL menggunakan SP RPL. Hasil menunjukkan bahwa SP RPL dengan sistem konversi yang diterapkan di PSPPI FT UGM merupakan prosedur dan sistem yang reliabel.

Kata kunci : Sistem penilaian, RPL, PSPPI, Statistik

Dipresentasikan: 30 Agustus 2019

Direvisi: 14 September 2019

Diterima: 2 Oktober 2019

Dipublikasikan online: 5 Oktober 2019

\section{Pendahuluan}

Fakultas Teknik Universitas Gadjah Mada (FT UGM) telah menjalankan Program Studi Program Profesi Insinyur (PSPPI) selama tiga tahun sejak 2017. PSPPI merupakan program pendidikan tingkat profesi yang diselenggarakan berdasarkan mandat Kemenristekdikti kepada 40 Perguruan Tinggi di Indonesia (Permenristek Dikti, 2016). Terdapat dua mekanisme penyelenggaraan pada PSPPI yaitu mekanisme reguler dan rekognisi pembelaran lampau (RPL). Penyelenggaraan program reguler dilakukan selama dua tahun dan terdiri dari proses perkuliahan dan praktik keinsinyuran di lapangan. Namun, peserta program PSPPI, khususnya di Fakultas Teknik Universitas Gadjah Mada (FT UGM), mayoritas telah memiliki pengalaman praktik pada bidang keinsinyuran minimal dua tahun. Oleh karena itu, selain jalur pendidikan reguler, program RPL dilakukan untuk melakukan penilaian berdasarkan pengalaman praktik.

Penilaian berdasarkan pengalaman praktik (program $\mathrm{RPL}$ ) menuntut sistem penilaian yang objektif, mudah, dan jelas. Di sisi lain, Persatuan Insinyur Indonesia (PII) telah menentukan bakuan kompetensi yang dapat dijadikan rubrik penilaian. Namun, sistem penilaian berbasis bakuan kompetensi ini dapat menjadi polemik bagi penilai. Tidak jarang para penilai menyatakan bahwa proses penilaian menjadi cukup rumit disebabkan banyak dokumen yang perlu diacu dan proses penilaian masih dilakukan secara manual. Selain itu, borang penilaian PII yang berbentuk form aplikasi insinyur professional (FAIP) belum dirancang untuk penilaian berbasis huruf untuk menghitung indeks prestasi (IP) yang digunakan dalam tataran Universitas. Dengan demikian, konversi penilaian dari nilai FAIP ke nilai IP perlu dilakukan. Konversi penilaian ini kemudian digunakan dalam pembangunan model untuk implementasi sistem penilaian RPL (SP RPL).

PSPPI FT UGM telah mengembangkan model dan sistem untuk penilaian RPL yang disebut SP RPL. SP RPL merupakan sistem berbasis spreadsheet yang berisi kolom- kolom penilaian kegiatan peserta yang terkait dengan mata kuliah-mata kuliah di PSPPI. Untuk setiap mata kuliah, seluruh bakuan kompetensi PII telah dipetakan sesuai kompetensi mata kuliah dan ditampilkan dalam bentuk pilihan yang tersedia bagi penilai. Hal ini memudahkan proses penilaian, terutama dalam mengacu pada bakuan kompetensi PII yang sesuai dengan mata kuliah. Penilai cukup memilih nilai yang sesuai untuk komponen pengalaman, peran, dan tingkat kesulitan dari setiap kegiatan yang terkait dengan masing-masing mata kuliah. Setelah nilai dipilih, seluruh penilaian untuk total RPL dan IP secara otomatis akan terhitung dan ditampilkan di SP RPL tersebut.

PSPPI FT UGM telah mengimplementasikan sistem penilaian RPL ini dalam proses penilaian peserta RPL pada beberapa periode pelaksanaan program. Dalam pelaksanaannya, penilaian untuk setiap peserta dilakukan oleh minimal dua orang penilai. Selanjutnya perlu dilakukan evaluasi apakah model konversi dan SP RPL PSPPI FT UGM telah reliabel. Reliabilitias dari SP RPL PSPPI FT UGM dapat dilihat dengan menganalisis apakah SP RPL telah menghasilkan hasil penilaian yang tidak berbeda signifikan antara satu penilai dengan penilai yang lain. Makalah ini berisi proses evaluasi SP RPL PSPPI FT UGM.

\section{Pembangunan Model Dasar dan Implementasi SP RPL}

\section{Pembangunan Model Dasar}

Model dasar SP RPL mengacu pada bakuan kompetensi PII. Satu SKS di PSPPI didefinisikan setara dengan dengan 25 skor Bakuan Kompetensi PII, sehingga 24 SKS PSPPI setara dengan 600 skor Bakuan Kompetensi PII.

Tatacara penentuan skor bakuan kompetensi PII mengacu kepada panduan dari PII terlampir pada lampiran. Nilai skor bakuan kompetensi (nilai aktivitas) dihitung dengan:

Cara mensitasi artikel ini:

Trapsilawati, F., Subagyo, Ariyanto, T., Herliansyah, M.K., Purwono, S (2019) Evaluasi Sistem Penilaian Rekognisi Pembelajaran Lampau. [Edisi Khusus]. Buletin Profesi Insinyur 2(3): 095-101 


$$
T=P Q R
$$

Dengan $T=$ nilai aktivitas $\mathrm{P}=$ nilai pengalaman; $\mathrm{Q}=$ nilai peranan; dan $\mathrm{R}=$ nilai tingkat kesulitan. Harga $\mathrm{P}, \mathrm{Q}$, dan $\mathrm{R}$ merupakan bilangan bulat antara 1 sampai dengan 4 dan nilai mengacu pada bakuan skoring PII.

Lebih lanjut, nilai matakuliah hasil rekognisi pembelajaran lampau dihitung dengan menggunakan nilai potensi $\left(T_{P}\right)$, untuk matakuliah A dengan bobot SKS sebesar $S_{a}$ yang penentuannya memakai persamaan:

$$
T_{P a}=\left(\frac{\sum_{i=1}^{n} Q_{i} R_{i}}{n}\right)
$$

Nilai $\mathrm{n}$ ditentukan dengan menggunakan:

$$
T_{a}=25 S_{a}
$$

Dan

$$
T_{a}=\sum_{i=1}^{n} P_{i} Q_{i} R_{i}
$$

Konversi nilai $T_{\mathrm{p}}$ menjadi skor nilai matakuliah dilakukan dengan menggunakan Konversi Ligyo FT UGM (Tabel 1). Di PSPPI FT UGM, nilai TP yang merupakan hasil perkalian antara $\mathrm{Q}$ dan $\mathrm{R}$ digunakan untuk menghitung nilai IPK.

Tabel 1. Konversi Nilai RPL dengan Konversi Ligyo FT UGM

\begin{tabular}{ccc}
\hline No. & $\mathrm{T}_{P a}$ & Skor RPL \\
\hline 1 & $1.00-3.20$ & $\mathrm{~B}$ \\
2 & $3.21-6.40$ & $\mathrm{~B}+$ \\
3 & $6.41-9.60$ & $\mathrm{~A} / \mathrm{B}$ \\
4 & $9.61-12.80$ & $\mathrm{~A}-$ \\
5 & $12.81-16.00$ & $\mathrm{~A}$ \\
\hline
\end{tabular}

Tabel 2 menunjukkan konversi bakuan kompetensi PII ke bakuan yang digunakan untuk setiap mata kuliah. Untuk lulus program Insinyur, peserta harus memenuhi 600 skor bakuan kompetensi yang setara dengan 24 SKS dan harus memenuhi distribusi minimum yang dipersyaratkan oleh PII, yaitu $W_{1}=60, W_{2}=180, W_{3}=120, W_{4}=60$, dan $P=180$. Peserta juga harus memiliki pengalaman sesuai dengan distribusi yang dipersyaratkan, sesuai dengan SKS setiap mata kuliah di PSPPI. Jika peserta program tidak memenuhi hal ini, maka mereka wajib mengambilnya dalam bentuk perkuliahan di PSPPI FT UGM. Lebih lanjut, untuk membantu proses penilaian, di PSPPI UGM, telah berhasil dibangun perangkat lunak komputer SP RPL berbasis spreadsheet yang dipaparkan lebih lanjut di Subbab Implementasi SP RPL.

\section{Implementasi SP RPL}

Perangkat lunak berbasis spreadsheet (SP RPL) telah dibangun untuk memudahkan sistem penilaian. SP RPL dapat digunakan oleh peserta RPL untuk pengisian RPL MK dan oleh penilai RPL untuk menilai RPL MK. Selain itu, nilai RPL dan IP dianalisis dan ditampilkan secara otomatis dalam SP RPL. Berikut penjelasan lebih lanjut untuk setiap bagian.

\section{Pengisian RPL Terkait Mata Kuliah}

Untuk memfasilitasi pengisian RPL terkait MK, dibuat halaman (sheet) untuk setiap MK. Pada halaman dengan judul "kode etik" (Gambar 1), peserta dapat menuliskan periode, instansi/perusahaan/organisasi/lokasi kegiatan, posisi jabatan, uraian kegiatan kolom-kolom yang tersedia. Setelah menuliskan empat informasi yang terkait kegiatan tersebut, peserta dapat memilih bakuan kompetensi yang sesuai dengan kegiatan yang diuraikan. Peserta dapat memilih bakuan kompetensi pada Tabel 2 dengan menekan "drop-down menu" di kolom uraian kompetensi dan memilih bakuan kompetensi yang sesuai (Gambar 2).

Setelah peserta memilih uraian kompetensi yang sesuai, kolom bakuan kompetensi dan kompetensi akan otomatis mengekstrak data nomor bakuan kompetensi. Data ini digunakan untuk menghitung sebaran bakuan kompetensi mata kuliah tersebut yang disesuaikan dengan sebaran bakuan kompetensi Persatuan Insinyur Indonesia (PII). Peserta diminta untuk melakukan hal-hal tersebut untuk seluruh mata kuliah PSPPI dengan mengisikan informasi di halaman yang sesuai, mulai dari halaman MK "kode etik" sampai halaman MK "profesionalisme".

\section{Penilaian RPL}

Setelah SP RPL diisi oleh peserta, file SP RPL akan dikirimkan ke majelis penilai. Majelis penilai akan menentukan nilai pengalaman, peranan, dan tingkat kesulitan dari setiap

\begin{tabular}{|c|c|c|c|c|c|}
\hline No. & Mata Kuliah & SKS & Bobot & Elemen Kompetensi & Uraian Kegiatan \\
\hline 1 & Kode Etik & 2 & 50 & W.1.1. W.1.2 & W.1.1.1-5, W.1.2.1-4, 1.2.6. \\
\hline 2 & Profesionalisme & 2 & 50 & W.1.2, W. 2.2 , W. 4.1 & $\begin{array}{l}\text { W.1.2.5, 1.2.7, 1.2.8, W.2.2.1- } \\
6, W .4 .1 .1 .\end{array}$ \\
\hline 3 & K3ILH & 2 & 50 & W.1.3. W.1.4. & W.1.3.1-7; W.1.4.1-5 \\
\hline 4 & Serninar & 2 & 50 & W.4.4. W.4.5 & W.4.4.1-6; W.4.5.1-9 \\
\hline 5 & Studi Kasus & 4 & 100 & W.2.1. W. $2.3-6$. & \\
\hline 6 & $\begin{array}{l}\text { Praktik Keinsinyuran } \\
\text { a. Filosoli Keinsinyuran di Industri } \\
\text { b. Arah perkembangan industri dan Status } \\
\text { c. Sistem Industri (Engineering) } \\
\text { d. Permasalahan Keinsinyuran } \\
\text { e. Tugas mengatasi Masalah } \\
\text { f. Penulisan laporan praktik keinsinyuran }\end{array}$ & 12 & 300 & $\begin{array}{l}\text { W.3.1-6, W. } 4.1-3 \text {, } \\
\text { ditambah minimal } 2 \mathrm{P}\end{array}$ & \\
\hline
\end{tabular}
kegiatan dengan memilih angka 1 hingga 4 di "drop-down menu" setiap kolom (Gambar 3).

Tabel 2. Perbandingan Matakuliah PSPPI dengan Bakuan Kompetensi PII 


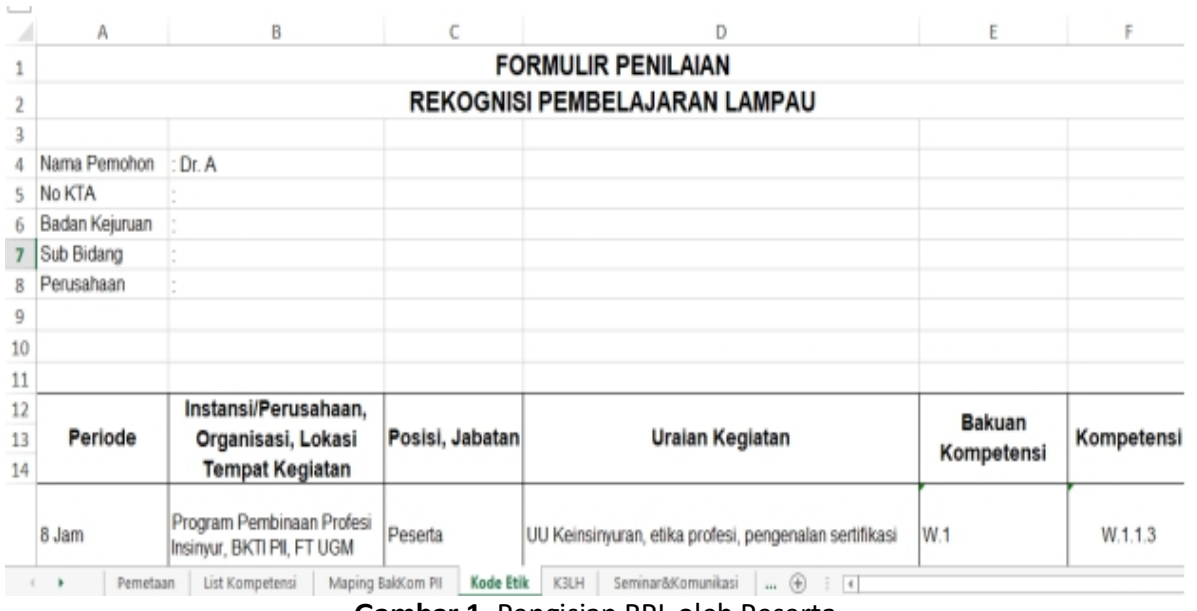

Gambar 1. Pengisian RPL oleh Peserta

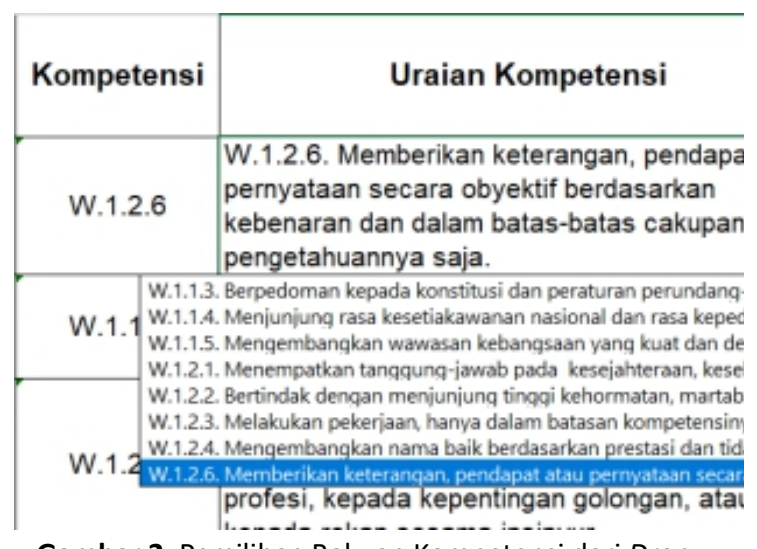

Gambar 2. Pemilihan Bakuan Kompetensi dari DropDown Menu

Nilai total RPL serta IP akan dihitung secara otomatis untuk setiap kegiatan. Jumlah total RPL dan rata-rata IP untuk setiap MK juga akan otomatis ditampilkan di bagian bawah setiap halaman. Nilai-nilai tersebut juga secara otomatis akan dikonversi menjadi nilai huruf dan nilai angka setiap MK menggunakan konversi Ligyo FT UGM pada Tabel 1. Selain itu, sebaran bakuan kompetensi RPL setiap MK juga secara otomatis ditampilkan di bagian bawah setiap halaman mulai dari W1 sampai W4 dan P (Gambar 4) untuk MK Wajib dan Pilihan, dengan logika "=SUMIF(Bakuan Kompetensi 1:N,"W.1",Bobot RPL 1:N)".
Khusus untuk mata kuliah studi kasus dan praktik industri, apabila peserta belum memenuhi nilai total RPL sebanyak 400 , peserta akan diminta untuk mengambil mata kuliah sesuai dengan yang ditunjukkan di halaman bawah SP RPL di bagian "keputusan" menggunakan fungsi logika if, "=IF(K28>=400,"Lulus SK dan PK",IF(K28>=300,"Ambil SK",IF(K28>=100,"Ambil PK","Ambil SK dan PK")))". Peserta akan diminta mengambil mata kuliah studi kasus dan praktik industri bila nilai RPL tidak sampai 100 . Bila nilai RPL diantara 100 dan 300, peserta diminta untuk mengambil mata kuliah praktik keinsinyuran. Namun bila nilai berada di antara 300 dan 400, peserta akan diminta mengambil mata kuliah studi kasus. Hal ini akan otomatis terlihat di SP RPL, sehingga penilai hanya perlu menyampaikan ke peserta bila masih ada mata kuliah yang perlu diambil.

\section{Hasil RPL dan IP}

Setelah majelis penilai mengisi penilaian untuk setiap kegiatan di seluruh halaman mata kuliah, nilai total RPL dan IP setiap mata kuliah akan langsung ditampilkan di halaman "total" yang berisi rangkuman penilaian serta sebaran distribusi bakuan kompetensi. Jika kegiatan RPL yang diisikan belum memenuhi sebaran bakuan kompetensi yang ditetapkan PII, maka di SP RPL akan ditunjukkan kata "KURANG". Nilai IP Kumulatif (IPK) akan langsung dihitung secara otomatis dan ditampilkan di halaman "total" (Gambar 5).

\begin{tabular}{|c|c|c|c|c|}
\hline \multirow{2}{*}{ Uraian Kompetensi } & \multicolumn{3}{|c|}{ Kode Etik (2 sks) } & \multirow{2}{*}{ Bobot RPL } \\
\hline & P & $\mathbf{Q}$ & R & \\
\hline $\begin{array}{l}\text { W.1.2.6. Memberikan keterangan, pendapat atau } \\
\text { pernyataan secara obyektif berdasarkan } \\
\text { kebenaran dan dalam batas-batas cakupan } \\
\text { pengetahuannya saja. }\end{array}$ & 3 &. & 4 & 36 \\
\hline $\begin{array}{l}\text { W.1.1.2. Menghayati dan senantiasa berusa } 1 \\
\text { mengamalkan nilai dan jiwa Pancasila dalam } \frac{2}{3} \\
\text { menjalankan profesi. }\end{array}$ & & 3 & 4 & 12 \\
\hline $\begin{array}{l}\text { W.1.2.1. Menempatkan tanggung-jawab pada } \\
\text { kesejahteraan, kesehatan dan keselamatan } \\
\text { masyarakat di atas tanggung-jawabnya kepada } \\
\text { profesi, kepada kepentingan golongan, atau }\end{array}$ & 3 & 3 & 4 & 36 \\
\hline
\end{tabular}

Gambar 3. Penilaian oleh Majelis Penilai 


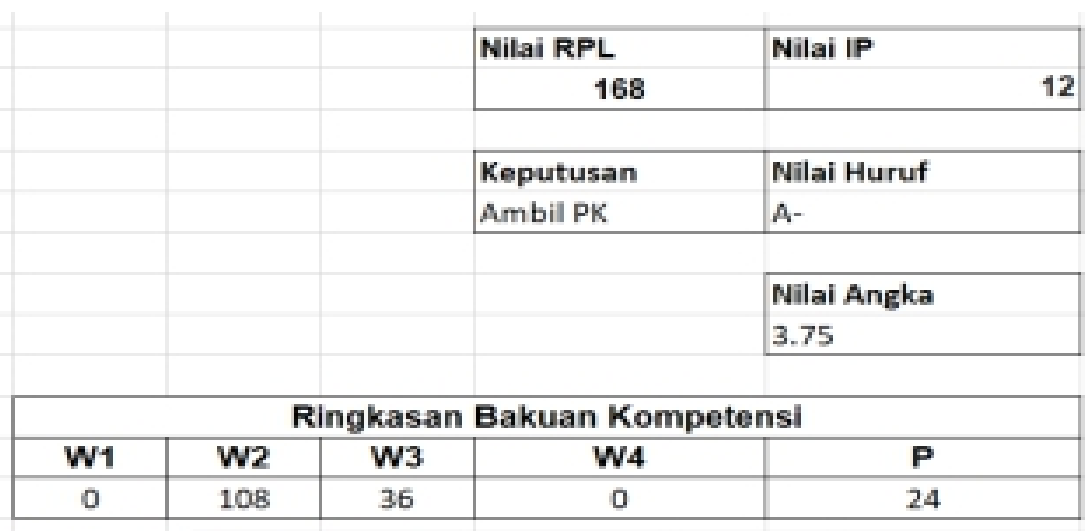

Gambar 4. Sebaran Bakuan Kompetensi

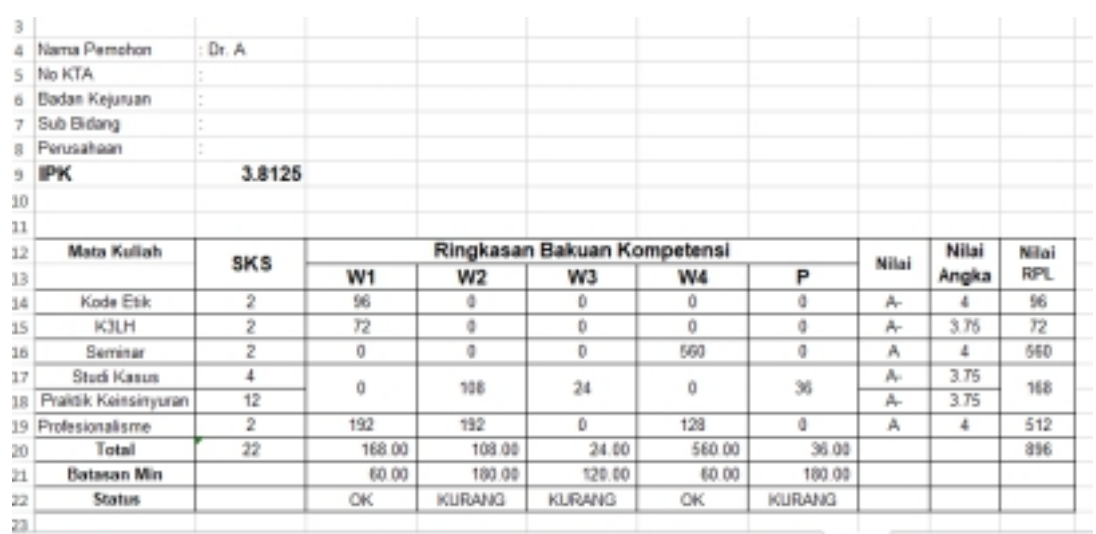

Gambar 5. Halaman Rangkuman

\section{Evaluasi SP RPL}

SP RPL yang mengadopsi konversi Ligyo FT UGM di dalam programnya, telah digunakan dalam proses penilaian peserta RPL pada beberapa periode. Penilaian RPL untuk setiap peserta dilakukan oleh dua penilai. Untuk melihat reliabilitas dari SP RPL yang menggunakan konversi Ligyo FT UGM, perlu dilakukan analisis apakah kedua penilai sepakat dalam melakukan penilaian. Hipotesis null yang diuji adalah tidak terdapat perbedaan signifikan antara hasil nilai kedua penilai untuk semua mata kuliah. Untuk menguji hal tersebut, metode yang digunakan adalah sebagai berikut

\section{Metode}

1. Obyek Evaluasi

Data nilai setiap mata kuliah dari 169 peserta RPL PSPPI FT UGM periode semester Genap 2019 digunakan untuk proses evaluasi SP RPL. Data yang digunakan adalah seluruh data nilai yang dihasilkan oleh kedua penilai untuk setiap peserta.

2. Instrumen Evaluasi

Evaluasi dilakukan dengan menggunakan Microsoft Excel dan Software JASP 9.2.0 untuk administrasi data dan analisis.

\section{Rancangan dan Prosedur Evaluasi}

Terdapat dua variabel yang diujikan dalam proses evaluasi, yaitu mata kuliah dan penilai. Terdapat dua level untuk variabel penilai, yaitu penilai 1 dan penilai 2 . Terdapat enam level untuk mata kuliah, yaitu Profesionalisme, Kode Etik,
Seminar, K3L, Studi Kasus, dan Praktik Keinsinyuran. Variabel penilai bersifat between-subjects dan variabel mata kuliah bersifat within-subjects, sehingga rancangan evaluasi ini berbasis mixed-design.

\section{Analisis Statistik}

Analisis statistik yang digunakan adalah Mixed-Design Analysis of Variance (ANOVA). Selain itu, uji Post-Hoc juga akan dilakukan jika ada variabel yang signifikan. Sebelum melakukan ANOVA, seluruh asumsi yang diperlukan, meliputi normality, sphericity, homogeneity diujikan terlebih dahulu mengikuti prosedur dalam (1).

\section{Hasil}

Uji asumsi Mixed-Design ANOVA menunjukkan bahwa asumsi normalitas dan homogenitas terpenuhi. Namun, asumsi sphericity tidak terpenuhi $\left(\chi^{2}(2)=0.005, p=0.001\right)$, sehingga derajat kebebasan diperbaiki dengan penyesuaian Greenhouse-Geisser $(\varepsilon=0.715)$ dan ditunjukkan pada hasil ANOVA. Rerata nilai mata kuliah oleh setiap penilai ditunjukkan pada Tabel 3.

Hasil analisis menunjukkan bahwa variabel penilai tidak berbeda signifikan, $F(1,334)=0.108, p=0.742, \eta^{2}=0.000$. Hal ini menunjukkan bahwa hipotesis null gagal untuk ditolak yang berarti tidak terdapat perbedaan hasil penilaian antara kedua penilai.

Selain itu, faktor interaksi antara penilai dan mata kuliah juga tidak berbeda signifikan, $F(3.58,1194.07)=$ $0.144, p=0.955, n^{2}=0.000$. Hasil ini menunjukkan bahwa tidak terdapat interaksi antara penilai dan mata kuliah yang 
berarti kedua penilai sepakat dalam penilaian di seluruh mata kuliah, sebagaimana ditunjukkan pada Tabel 4.

Tabel 3. Statistik Deskriptif

\begin{tabular}{|c|c|c|}
\hline Mata Kuliah & Penilai Rerata & SD \\
\hline \multirow[t]{2}{*}{ Kode Etik } & 13.769 & 0.235 \\
\hline & 3.765 & 0.256 \\
\hline \multirow[t]{2}{*}{ K3LH } & 3.677 & 0.263 \\
\hline & 3.685 & 0.275 \\
\hline \multirow[t]{2}{*}{ Seminar } & 3.536 & 0.218 \\
\hline & 3.527 & 0.215 \\
\hline \multirow[t]{2}{*}{ Studi Kasus } & 3.609 & 0.247 \\
\hline & 3.595 & 0.240 \\
\hline \multirow[t]{2}{*}{ Praktik Keinsinyuran } & 3.609 & 0.247 \\
\hline & 3.597 & 0.242 \\
\hline \multirow[t]{2}{*}{ Profesionalisme } & 3.548 & 0.242 \\
\hline & 3.540 & 0.242 \\
\hline
\end{tabular}

Tabel 4. Hasil Uji Statistik Penilai untuk Setiap Mata Kuliah

\begin{tabular}{|c|c|c|c|c|c|}
\hline \multicolumn{6}{|c|}{ Kuliah } \\
\hline $\begin{array}{l}\text { Level of Mata } \\
\text { Kuliah }\end{array}$ & $\begin{array}{l}\text { Sum of } \\
\text { Squares }\end{array}$ & $d f$ & $\begin{array}{l}\text { Mean } \\
\text { Square }\end{array}$ & $\mathrm{F}$ & $p$ \\
\hline Kode Etik & 0.002 & 1 & 0.002 & 0.028 & 0.868 \\
\hline K3LH & 0.005 & 1 & 0.005 & 0.064 & 0.800 \\
\hline Seminar & 0.007 & 1 & 0.007 & 0.143 & 0.706 \\
\hline Studi Kasus & 0.015 & 1 & 0.015 & 0.254 & 0.615 \\
\hline $\begin{array}{l}\text { Praktik } \\
\text { Keinsinyuran }\end{array}$ & 0.012 & 1 & 0.012 & 0.199 & 0.656 \\
\hline Profesionalisme & 0.005 & 1 & 0.005 & 0.080 & 0.778 \\
\hline
\end{tabular}

Faktor mata kuliah menunjukkan hasil yang berbeda signifikan $F(3.58,1194.07)=81.102, p=<0.001, \eta^{2}=0.195$. Hasil ini menunjukkan bahwa nilai mata kuliah berbeda antara satu mata kuliah dengan mata kuliah lainnya. Hasil uji Post-Hoc pada Tabel 5. menunjukkan bahwa nilai perbandingan antar mata kuliah berbeda kecuali antara Seminar dan Profesionalisme $(p=1.000)$ dan Studi Kasus dan Praktik Keinsinyuran $(p=1.000)$.

\section{Pembahasan}

Paper ini membahas tentang pengembangan sistem konversi dan model matematis serta sistem penilaian berbasis spreadsheet untuk penilaian RPL. Sistem penilaian RPL telah diimplementasikan di PSPPI FT UGM selama beberapa periode dan telah berjalan dengan baik dari sisi teknis. Namun, perlu dilakukan analisis untuk mengevaluasi apakah sistem SP RPL yang mengadopsi Konversi Ligyo FTUGM merupakan instumen yang reliabel dalam penilaian ketika digunakan oleh penilai yang berbeda-beda.

Hasil analisis menunjukkan hal yang menarik. Pertama, SP RPL terbukti merupakan sistem yang reliabel ditunjukkan dengan hasil penilaian yang tidak berbeda signifikan antara seluruh penilai di seluruh mata kuliah, sebagaimana ditunjukkan pada Gambar 6. Hal ini menunjukkan bahwa dengan prosedur yang dikembangkan PSPPI FT UGM, seluruh penilai yang memiliki background pendidikan berbeda dapat bersepakat dalam hal penilaian, sesuai dengan penelitian terdahulu (2). Dengan begitu sistem ini dapat digunakan oleh penilai dan memberikan hasil yang reliabel untuk seluruh mata kuliah.

Tabel 5. Hasil Uji Post-Hoc - Mata Kuliah

\begin{tabular}{|c|c|c|c|c|c|}
\hline & & Mean & & & \\
\hline & & $\begin{array}{l}\text { Differen- } \\
\text { ce }\end{array}$ & SE & $\mathrm{t}$ & $\mathrm{p}$ bonf \\
\hline Kode Etik & LH & 0.086 & 0.015 & 5.693 & $<.001$ \\
\hline & Seminar & 0.236 & 0.014 & 16.825 & $<.001$ \\
\hline & Studi Kasus & 0.165 & 0.016 & 10.649 & $<.001$ \\
\hline & $\begin{array}{l}\text { Praktik } \\
\text { Keinsinyuran }\end{array}$ & 0.164 & 0.016 & 10.597 & $<.001$ \\
\hline & Profesionalisme & 0.223 & 0.016 & 13.614 & $<.001$ \\
\hline $\mathrm{K} 3 \mathrm{LH}$ & Seminar & 0.150 & 0.014 & 10.367 & $<.001$ \\
\hline & Studi Kasus & 0.079 & 0.015 & 5.089 & $<.001$ \\
\hline & $\begin{array}{l}\text { Praktik } \\
\text { Keinsinyuran }\end{array}$ & 0.078 & 0.015 & 5.043 & $<.001$ \\
\hline & Profesionalisme & 0.137 & 0.015 & 8.995 & $<.001$ \\
\hline Seminar & Studi Kasus & -0.071 & 0.013 & -5.475 & $<.001$ \\
\hline & $\begin{array}{l}\text { Praktik } \\
\text { Keinsinyuran }\end{array}$ & -0.071 & 0.013 & -5.529 & $<.001$ \\
\hline & Profesionalisme & -0.013 & 0.012 & -1.041 & 1.000 \\
\hline Studi Kasus & $\begin{array}{l}\text { Praktik } \\
\text { Keinsinyuran }\end{array}$ & -0.001 & 0.001 & -1.000 & 1.000 \\
\hline & Profesionalisme & 0.058 & 0.013 & 4.410 & $<.001$ \\
\hline $\begin{array}{l}\text { Praktik } \\
\text { Keinsinyuran }\end{array}$ & Profesionalisme & 0.059 & 0.013 & 4.477 & $<.001$ \\
\hline
\end{tabular}

Kedua, terdapat perbedaan signifikan antara masingmasing mata kuliah. Seperti ditunjukkan pada Gambar 6, mata kuliah seminar dan profesionalisme merupakan dua mata kuliah yang menghasilkan nilai terendah. Hal ini mungkin disebabkan oleh kurangnya paparan peserta yang mayoritas berasal dari perusahaan terhadap kesempatan menyampaikan ide atau gagasan kepada khalayak melalui seminar. Mata kuliah kode etik menunjukkan nilai tertinggi. Hal ini menunjukkan hal yang positif bahwa peserta yang merupakan sampel dari pekerja di Indonesia memiliki etik yang baik. Menimbang hasil nilai pada Gambar 6, hal yang mungkin perlu ditingkatkan untuk mendorong suksesnya peran Indonesia di Masyarakat Ekonomi ASEAN (MEA) adalah kemampuan teknis.

\section{Kesimpulan}

Paper ini berisi penjelasan konversi penilaian dari bakuan kompetensi PII ke nilai IP pada tataran Universitas. Sistem konversi ini kemudian diterapkan pada pengembangan model matematis serta pengembangan sistem penilaian RPL. Sistem penilaian RPL ini kemudian telah diimplementasikan dalam perangkat lunak berbasis spreadsheet untuk membantu proses penilaian, baik bagi peserta RPL maupun bagi penilai. Bakuan kompetensi PII yang telah dipetakan untuk setiap mata kuliah di PSPPI juga telah dimasukkan di dalam SP RPL untuk dipilih secara otomatis.

Implementasi SP RPL selanjutnya dievaluasi di paper ini. Hasil analisis menunjukkan bahwa tidak ada perbedaan signifikan antara seluruh penilai untuk seluruh mata kuliah. Hal ini mengindikasikan bahwa SP RPL yang mengadopsi Konversi Ligyo FT UGM merupakan prosedur dan instrumen yang valid dalam penilaian RPL. 


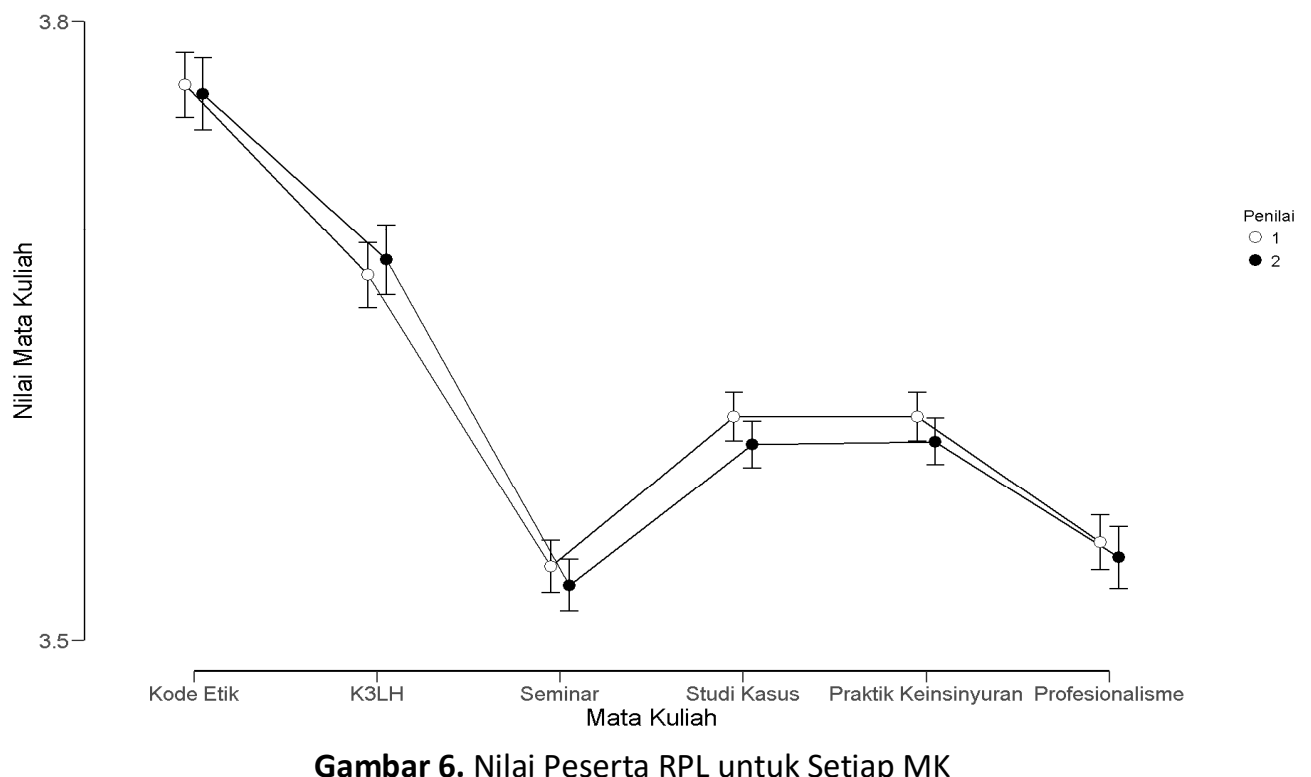

Selain itu, hasil analisis juga menunjukkan bahwa peserta yang merupakan sampel dari populasi pekerja di perusahaan di Indonesia telah menjunjung tinggi kode etik. Namun, kemampuan teknis masih terus perlu ditingkatkan, terutama dalam hal penyampaian ide atau gagasan kepada khalayak dalam bentuk seminar teknikal.

\section{Referensi}

Montgomery, D. C., (2017) Design and analysis of experiments, John wiley \& sons, New Jersey.
Moskal, B. M., Leydens, J. A., \& Pavelich, M. J., (2002) Validity, reliability and the assessment of engineering education. Journal of Engineering Education, 91(2002): 351-354.

Peraturan Menteri Riset, Teknologi, dan Pendidikan Tinggi Republik Indonesia, No. 35 Tahun 2016 tentang Penyelenggaraan Program Studi Program Profesi Insinyur. 